FILOLOGIJA 68, Zagreb 2017.

\author{
Johannes Reinhart \\ Institut für Slawistik \\ Universität Wien \\ Spitalgasse 2-4, Hof 3, A-1090 Wien \\ johannes.reinhart@univie.ac.at
}

UDK 811.163.42'374'0:81'366

https://dx.doi.org/10.21857/mnlqgc0v0y Izvorni znanstveni članak

Primljen 30.IV.2017.

Prihvaćen za tisak 25.IX.2017.

\title{
RIJETKE RIJEČI U RJEČNIKU CRKVENOSLAVENSKOGA JEZIKA HRVATSKE REDAKCIJE ${ }^{1}$
}

\begin{abstract}
U članku se opisuju riječi u Rječniku crkvenoslavenskoga jezika hrvatske redakcije koje nisu oprimjerene ni u Praškom staroslavenskom rječniku ni u Miklošičevu crkvenoslavenskom rječniku ni u Akademijinu rječniku. Neke su od tih riječi vlastita imena iz Biblije ili iz drugih prevedenih tekstova koje nisu bile uzimane u obzir. Mali dio riječi koje se ne susreću u navedenim rječnicima tvorbene su inačice drugih riječi koje su dobro potvrđene $\mathrm{u}$ hrvatskom crkvenoslavenskom ili u starohrvatskom jeziku. Ostale riječi koje nisu oprimjerene u drugim rječnicima - ni u suvremenom hrvatskom jeziku - pružaju dobar uvid u povijest hrvatskoga jezika.
\end{abstract}

U najtočnijoj analizi fonda staroslavenskih riječi, predstavljenoj u knjizi Ralje Mihajlovne Cejtlin Лексика старославянского языка (Moskva 1977), razlikuju se dvije skupine hapaksa (Cejtlin 1977:40-41):

(1) Riječi, koje su dobro potvrđene u leksiku crkvenoslavenskome različitih redakcija kao i leksiku književnih i dijalekatskih slavenskih jezika, ali u staroslavenskome dolaze samo jedanput (npr. baba, brdrostb, vesna);

(2) Riječi, koje drugdje nisu uopće oprimjerene (npr. dlıgoslužie, neizdrečenonikb, synobožbstvie).

Dok su hapaksi prve skupine mnogobrojni, broj riječi druge skupine

\footnotetext{
${ }^{1}$ Zahvaljujem dr. Ani Kovačević (Zagreb) na jezičnoj korekturi članka i na cijelom nizu sadržajnih savjeta.
} 
Johannes Reinhart: Rijetke riječi u Rječniku crkvenoslavenskoga jezika hrvatske redakcije FILOLOGIJA 68(2017), 157-169

je ograničen. Hapaksi druge skupine dolaze ponajprije u Euhologiju sinajskome i u Suprasalskom rukopisu. Njih bismo mogli nazvati okazionalizmima, iako R. M. Cejtlin od toga preza. Prvobitno sam rad htio nazvati "Hapakslegomena u Rječniku crkvenoslavenskoga jezika hrvatske redakcije«, ali nisam jer su riječi, kojih nema u tri uspoređena rječnika - Praškom staroslavenskom, Miklošičevu crkvenoslavenskom i u Akademijinu rječniku ponekad potvrđene više puta u jednom ili u nekoliko hrvatsko-crkvenoslavenskih spomenika.

U članku se uzimaju u obzir prva dva sveska Rječnika. U prvom svesku ima, ako zanemarimo osobna imena, 306 riječi, kojih nema u spomenuta tri rječnika, a u drugom svesku ima 262 takve riječi. Među njima je 75 hapaksa u prvom svesku, a 131 hapaks u drugom svesku, i 74 odnosno 64 posuđenice u dva sveska, djelomice takvih, koje su odavna ušle u slavenske jezike (npr. biskupstvie, vskralevstvovati, vcêsar'stvovati).

Ukupni broj natuknica u prvom svesku iznosi 2065 (2062 + 3 dopunske riječi), dok drugi svezak broji ukupno 2054 (2051 + 3 dopunske riječi) natuknice.

U ovom su istraživanju izostavljeni posvojni pridjevi na $-j$ - (npr. gorgans ${ }^{2}$; diên ‘ 'Dijanin'; edinorožb 'jednorogov'; Elanı 'Elin, of Elah'), ali su uzeti u obzir pridjevi na -bsk-, derivirani od toponima, što bi se moglo kritizirati kao određena nedosljednost. Kod posuđenica nismo uračunali složenice s prvom sastavnicom arhi-.

Obrađene »rijetke riječi« prvoga sveska Rječnika, dakle one, kojih nema u tri spomenuta rječnika, jesu sljedeće2:

ava, ave, aganıskb, agiosb, ag'ncičb, agonb, adoukatusb, ainb, aionb, akvienıskь, akkaronıskь, akra, akratomıskb, akrimoniê, aksamitınь, almužna, alno, alpaedo, alfavita, amalêčaninь, amalêčıskb, amanitıskb, amarimidimb, ambienšbskb, ametistusb, amorêi, ampiteatrı/amfiteatrı, ampora, angli, andriêntı, anĵelikı, annь, antiponıskb, apoplinı, apustolstvie, apustolb ${ }^{2}$, araklêiskb, aramata ${ }^{1}$, arenariê, ariolb, aristorb/ aristorii, arodii, aromatizati, arhidêlatelb, arhierêistvie, arhikrovbcb, asižbskı, askupa, atanatosı, atusb, aferı, afrikь, ahaiti, balina, balinbskb, balovatelınь, balstvınь, basilika, batorno, bdeliumb, bditelnê, b'drê, bezavistno, bezvêrstvie, bezdarınь, bezdêlma, bezlêpie, beznadı, bezračunsnь, bezuma, besvêtnikb, besvêtınь ${ }^{2}$, beskonočno, beslušlivb, besprêstamne, besprêstana, besprêstannê, best'kmenьnь, bestudnica, bestudno, besumno,

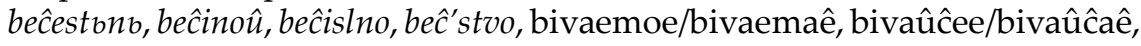
bivšaê, bienniumb, bizanıskb, biskupstvie, bistrina, bitiiskь, blagoboênie, blagovolno, blagovolstvie, blagovêstitelb, blagovêstno, blagodêtel ${ }^{2}$,

\footnotetext{
${ }^{2}$ Kurzivom su obilježeni hapaksi, masnim slovima posuđenice.
} 
Johannes Reinhart: Rijetke riječi u Rječniku crkvenoslavenskoga jezika hrvatske redakcije FILOLOGIJA 68(2017), 157-169

blagodêtstvie, blagodêtstvo, blagolûbie, blagoobilie, blagoprêbivanie, blagoredınь, blagos'vrıšens, blagostivê, blagostno, blagotvorie, blagot'čbnv, blagougodno, blagougodnê, blagouredie, blagohodožnikı, blagoč'stvie, blagoč'tbcb, blagočbstnê, blažstvovati, bližičstvie, bliž'stvo, blizn'stvenь/ bliznьč'stvınь/blizn'čsstvenь, blêdênie, blûditelı, bndra (!), bogolûbiti $(!)^{3}$, bogoobêtını, bož'stvie/božınstvie, bolonsskb/bolonêiskb, botronb, boêznivê, boêtelınь, bragmane, brazgati, brazditi, branstvo, brat'rıstvie, bregmlênı, brecati, bridko, britonıskь, broĉsnь, brıženič'stvie/brıženstvie, brıžitelınь, brıžitı, brınьnь ${ }^{1}$, bubnačnica, bue, bue(v)stvo, burgunıskь, burnêi, buênie, bêgavb, bêdnotrıpnê, bêtb, vala, vandalıskb, vap'šen $t a$, vasanitidinıskь, vasanbnb, vaĉenie, vaĉin knuti se, vvrsženie, vdovina, vdovstvie, vdupliti, vdêdiciti, vdêti ${ }^{2}, v^{\prime} e d i n a n v$, vekati, veliko, veličenie, veličnê, velmožni, velmožno, versavitıskı, versьcь/veršbcь/beršьcь, večeratelnica, večernenь, vželêtelbnv, vzbarati, vzbožnê/vzbožno, vzbožbnь, vzboreniê, vzboritelno, vzboritelınь, vzboriti se, vzbranitelь, vzbrati, vzbuždevanie, vzveselenie, vzvraĉevati, vzvrbčiti, vzvêrovanie, vzvêstovanie, v'zvêĉevati, vzglbtiti, vzgnušanie/vzgnušenie, vzgospodstvovati, vzgrıdati, vzgrımitelı, vzdanie ${ }^{2}$, vzdvignenie, vzdvižanie, vzdilanie, vzdimati se, vzdihanınь, vzdlıbiti $(!)^{4}$, vzdražati se, vzdruženie, vzdrbznovenie, vzdrshniti se/vzdrıhnêti se, vzduti, vzdušati, vz'ečevati, vzžalovati, vzloviti, vzlêditi (recte: vzlediti), vzmožno, vzmožnê, vzmož'stvie, vzmrbzstvovati, vzmuĉevati, vzmucati, vzmêstiti se, vznezdraviti, vznošavati, vzobitovati se, vzobrêzati, vzobrêsti, *vzobêtovanie, vzorice, vzravniti se, vzročstvo, vzrbzati, vzužasati, vzučiti ${ }^{1}$, vzčeti, vzčisti ${ }^{2}$, vzьpь, vivariti, vivesti, vivrêĉi, vidimê, vidênь, viknutie, vimesti, vindinıskь/ vindiiskb, vinesenie, vineti, vinositi, vipirina, vipiti, vipluti, viprostirati, viprostrêti, vipustiti, vipuĉati, virovati, visokozučsnь, visoč'stvie, vistupanie, vistupati, viteževati, vitrıgnuti, vitrêbiti, vihoždenie, viš'stvie, viš'stie, viêvica, vladatelstvo, vlaziliĉe, vlaspimiti, vlaĉeta, vlaĉ'stvie, vlbšvenь, vmanınь, vmênevati, vnaglê, vnimatelno, vnutru, v'nınь, voboružiti se, v'obrazovatelnica, vodnati se, vodorêčsnь, vodotrudınь, voevodstvie, voždınь, voiĉenь, v'oruževati, v'oruženie, v'oružie, v'ostriti, vplıznuti, vproplbĉenie, vrač'stvie, vračs ${ }^{2}$, vrinovati, vrut'čscь, vrıhovstvie, vrıšba ${ }^{2}$; bišekstb $(\Sigma=306)$.

Obrađene »rijetke riječi« drugoga sveska Rječnika, dakle one, kojih nema u tri spomenuta rječnika, jesu sljedeće:

vrêcicînınv, vrêĉice, vsakžde/vsakže, vsakoêki, vsakoêcê, vsiênie, vskliknutie, vsklopiti, vsklbčiti, vskoreniti se, vskralevstvovati, vskrêsitelno, vskrêševati, vskrêšens, vspakostiti, vspeti, vspitatelnica,/vspitêtelnica, vspitovati, vspitênikь, vsplesti, vsplêtati, vspominb, vsponositi, vspočivati, vspočinuti,

\footnotetext{
${ }^{3}$ RCJHR I:218, s.v. bogolûbiti: »non nisi loco corrupto «.

4 Stariji infinitiv glasi -dlêsti, usp. izdlesti kod Antuna Dalmate, v. RHSJ 4 (Isprekrižati - Kipac), 1892-1897:164, s.v. izdupsti.
} 
Johannes Reinhart: Rijetke riječi u Rječniku crkvenoslavenskoga jezika hrvatske redakcije FILOLOGIJA 68(2017), 157-169

vsprinositi, vspriĉati, vsprorecii, vsprêlûbodêêti se, vsprêĉavati/vsprêceevati, vspuĉenv, vstanutie, vstlêci $i$, vstočsnь ${ }^{2}$, vshitovati, vshiĉevati, vshicenica, v'scvisti, vtai, vtainê, vhoditelb, vhodoč'stvo, vcêsar'stvovati, včediti, včeladiti, vbzv'nêti, vbzd'hnovenie, vbzd'hovati, vbzm'ĉenie, vbz'spati, vbm'ĉenie/ um'ĉenie, voplstvovati, vêd'rıčce, vêrimb, vêritelno, vêritelnê, vêrovatelnê, vêrovatelınь, vêrovêrbnı, vêrstvie, vêrbnstvie, vêste, vêĉstvo, vêĉnnstvo, vêčnota, vêčnê, vûtrê, gavaonıskb, gazarinıskb, galaaditêne, galičbskb, galiêni, gbotrb, gvozdinınь, gigantovb, glavotegb, glagolitelbnb, glasito, glasovznošenie, gluboko, glubokostb, glumka, glıtuniê, glbtunb, gnesivb, gnilnikb, gnilb ${ }^{1}$, gnusitb, gozambskb, goneziti, gorupno, gorupostb, gorupb, goruĉe, gorušsnb, gorêtelno, gotovanie, grabželi, gravaonbskb, graviê, gramota $^{1}$, gramota ${ }^{2}$, gramotiti, grapiûnb, grebiê, grıdie, grıličı, grêênie, gurelı/ gurêlb, dakalitra, daletı, daleč'stvo, damatênbskb, datelnica, daciêne, dvoinoû, dvoičstvo, dvornostb, dvoustatb, d'gna (!), d'gota (!), dekšesta, derezlivb, desetnakı, diapsalma, didaskalı, dieli, dikanı, dikovanie, dikovati se, diêlozi, diêfoniê, dlıga, dlıgoželêtelınь/dlıgoželênь, dlıgotınь, dobditelı, dobrovolenie, dobrodarstviti, dobroobrbven ti, Dodamblı/dodamilıskb, dozrênie, doizglagolati, doizgovoriti, doizreĉi, doikinb, doica, dokasati (se), dombskb, dopoznati, dosaditelno, dosaždatelb, dosežını, dostoênstvie, dosızdati, dočestiti, dragalasiiskb, drakunb², dreselonı, driliška, drugoviceû, drugovb, drugb ${ }^{3}$, družie, družinstvie, dručiti se, drbžavno, drıžatelı, drbželı/drıžalı, drbžitelb, drızimı, drbznovati (se), drbzovati, drızu, drıhьtь, drêvie, drêvlostı, drêvolı, dubalı/dubaliê, dubьcь, dunastb, dupleksь, dupliti, duplo ${ }^{1}$, duhova, duhovnê, dučiti, dušegubivb, dušelovica, dıêbolika, dêvstvie, dêtirb, $e^{3}$, ebroničbskb, ebronbskb, evoa, evêi/evb, edinovlastı/edinovlastını, edinozračını, edinokolênnikb, edinosuĉstvie, edinot'čınь, edinstonê, edomitb, eklisasb, ekšorcista, ekšumenıskb, ekь, elefanciê, elikori, eliokbskb, elicêmb, ematelı, emoroi$z a, e n$, eneralb, encenoê, episkupstvenb, eretničb, eropolitanıskb, erêistvie, estb, estbstonê, etambskb, etb, etêi, efebь, efebêi, ešuts ${ }^{2}$, ešutınь, žalovanie, želêsnivo, želêsnivb, želêsbnv, želêtelıno, žetelb ${ }^{2}$, žživlati, živite, žrblıcь ${ }^{1}$, žrstvbcь/žrstnikь, žrstie ${ }^{2}$, žusta, zabivanie, zavidlivo, zavrêsti, zaglaždenie, zagrest ${ }^{2}$, zagublati, zadaêti, zadovoleučinenie, zazviznuti, zai, zaistinu, zaklaplati, zakonoprêstupnê, zamêriti, zapečatlati, zaplêtati; dobrovêsto $(\Sigma=262)$.

Što se tiče nepotvrđenosti netom navedenih riječi u spomenuta tri rječnika, pouzdao sam se u podatke rječnika. Na jedan slučaj gdje sam to ipak provjerio, vratit ću se malo kasnije. Moguće je da su još neke riječi isto tako posuđenice (npr. dubalv/dubaliê 'svila, fina lanena tkanina'), ali za to bi trebalo više podrobnih istraživanja.

Za usporedbu navodim nekoliko hapaksa, koji se ipak nalaze i barem u jednom od triju spomenutih rječnika (takvih je 254 riječi, od kojih su 22 osobna imena, što znači da je apelativa 232): vsklevetati (BrVO), vslanati 
Johannes Reinhart: Rijetke riječi u Rječniku crkvenoslavenskoga jezika hrvatske redakcije FILOLOGIJA 68(2017), 157-169

se $(\mathrm{BrVO})$, vspitati $(\mathrm{BrPm})$, vspluti $\left(\mathrm{BrN}_{2}\right)$, vsplûvati $(\mathrm{CPar})$, vsteklı $\left(\mathrm{BrN}_{2}\right)$, vcêsarevati (PsFr), voplstvie (BrVO), vêica (CŽg), gložie (BrVO), glubosto (CŽg), govorlivo $\left(\mathrm{BrN}_{2}\right)$, grabiti (CBč), gugnivo (BrLab), dvoica $\left(\mathrm{BrVat}_{5}\right)$, dozvati (COxf), dopadati (RegBen), dreselivb (RegBen), druža (BrVat $\left.{ }_{6}\right)$, edinomužica (CBč), epopsa (CAc), zavaditi (BrVO), zagvozditi (BrLab), zažganie (CPet), zapaliti (BrVO).

Citat iz recenzije Emilije Bláhove prvih pet sveščica Rječnika ${ }^{5}$ jasno govori da definicija riječi kao »rijetke« (ona to naziva »hapakslegomenon«) ovisi o broju uspoređenih rječnika. Potvrđuju to i tri obrađena leksema u Rječniku koji izostaju u prethodno navedenim rječnicima, ali kada se usporedbi pridoda staroruski rječnik XI.-XIV. stoljeća, tri riječi iz Rječnika gube svoj ekskluzivan karakter: vozd'hnovenie - vъzdrbchnovenije (SDJa II:47); didaskalb - didaskalb (SDJa II:467); gluboko - gluboko (SDJa II:331). Poseban je slučaj riječ adoukatusb, koje u praškom staroslavenskom Rječniku zbilja nema, ali se može naći u dopunama toga rječnika s potvrdom u crkvenoslavenskom prijevodu evanđeoskih homilija Grgura Velikoga ${ }^{6}$.

Važan je aspekt pri analizi leksika korpusnog jezika tvorba riječi. ${ }^{7}$ To se može ilustrirati građom vezanom sa šest tipova tvorbe riječi koji imaju važnu ulogu u istraživanju. Riječ je o sljedećim derivacijskim modelima: predmetak vi-, predmetak vz-/vs- za izraz budućnosti, tvorba priloga, imenice sa sufiksom -stvie, pridjevi ili prilozi sa sufiksom -telsn-, te sufiksalni sinonimi.

Hrvatsko-crkvenoslavenski jezik - kao i neki slovenski i sjevernočakavski dijalekti ${ }^{8}$ - dijeli izoglosu sa zapadnoslavenskim i istočnoslavenskim jezicima po tome što u svima postoji prefiks vi- ( $\left.{ }^{*} v y-\right)$. Navest ćemo glagole iz prvog sveska Rječnika kojih nema u tri spomenuta rječnika: vivariti, vivesti, vimesti, vinesenie, vineti, vinositi, vipirina, vipiti, vipluti, viprostirati, viprostrêti, vipustiti, vipuĉati, vistupanie, vistupati, vitrognuti, vitrêbiti, vihoždenie, viš'stvie, viš'stie.

Slično tomu, karakteristična je osobina hrvatske redakcije prefiks vz-/ vs- kao izraz budućnosti. Citirat ćemo ovdje mali izbor takvih prefigiranih glagola - njih ima znatno više: vzglbtiti, vzgospodstvovati, vzloviti, vzužasa-

\footnotetext{
5 »Některá hapaxlegomena, nedoložená v žádném ze srovnávaných slovníků, jsou však izolovaná jen zdánlivě.« (Bláhová 1997:222).

6 SJS V:41, s.v. *advokatušb.

${ }^{7}$ Usp. »V řádě případů jsou v charv.-hlah. památkách doloženy jiné deriváty téhož kořene, než jaké dokládá SJS z materiáku staroslověnského, nap̌̌. broĉb purpur coccinum a broĉbnb purpureus (v SJS jen оврочнтн) ...« (Bláhová 1997:222).

${ }^{8}$ Usp. npr. Pićan: vibràt, vignàt, vilès/vilazàt, vinèt (Ružić Sudčev 1999); Orlec: vìlas 'right to pass', vinut 'take out' (Houtzagers 1985). Usp. također Lencek 1993:349-351.
} 
Johannes Reinhart: Rijetke riječi u Rječniku crkvenoslavenskoga jezika hrvatske redakcije FILOLOGIJA 68(2017), 157-169

ti, vskoreniti se, vskralevstvovati, vspakostiti, vsponositi, v'scoisti.

Kod priloga kojih nema u tri uspoređena rječnika uočavamo sljedeću sliku: ponekad postoji druga tvorba priloga, ponekad pridjev s kojim je prilog u derivacijskoj ovisnosti: vsakoêcê - vsakoêko - vsakoêki; vêritelno vêritelnê; vêritelnê - vêritelno; vêrovatelnê - vêrovatelbnb; vêčnê - vê̌nno vếčnb; glasito - glasitb; gluboko - glubokb; goruce - goruĉb; drbžavno -

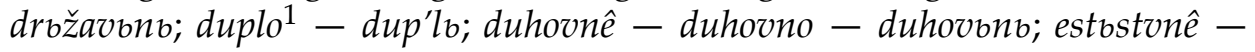
est'stobnb; zavidlivo - zavidlivb; zakonoprêstupnê - zakonoprêstupъnь.

U oba sveska Rječnika razmjerno su dobro zastupljeni pridjevi ili pri-

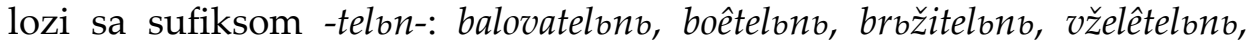
vzboritelbnb; vskrêsitelno, vêritelno, vêritelnê, vêrovatelnê, vêrovatelınb, glagolitelınь, gorêtelno, dlogoželêtelıno/dlogoželênb, dosaditelno, želêtelıno. Oni su - kako sam pokušao dokazati prije tri desetljeća ${ }^{9}$ - specifična hrvatsko-crkvenoslavenska osobina, tj. ne potječu iz nekog drugoga slavenskog jezika ${ }^{10}$, ali nisu potvrđeni ni u kasnijim jezičnim razdobljima.

U hrvatsko-crkvenoslavenskom jeziku dosta su često zastupljene rijetke riječi sa sufiksima uz koje postoje bliskoznačne izvedenice s drukčijim sufiksima koje su uglavnom uobičajenije: vếnnota - vế̌bnstvie, vế̌̌nstvo; vêĉ́bnstvo - vêêstvo; gnusito - gnusbnv; dvoičstvo - dvoenie; dosaždatelv dosaditelv; vskliknutie - vskliknovenie; vstanutie - vstanie.

Velik je broj rijetkih riječi koncentriran u nekoliko hrvatskoglagoljskih spomenika: u II. novljanskom brevijaru (iz 1493. g.; $\mathrm{BrN}_{2}$ ), u Brevijaru Vida Omišljanina (iz 1396. g.; BrVO), u Pariškom zborniku br. 73 (ili u Borislavićevu zborniku; iz 1375. - 1379. g.; CPar), te u Fraščićevu psaltiru (iz 1463. g.; PsFr):

$\mathrm{BrN}_{2}$ : aionb, besvêtnikb (!), blagouredie, blagoč'stvie, buênie (?), vap'šenb, vzbrati, vzgrodati, vimesti, viteževati, voevodstvie; vrêcîĉbnb, vsakžde/vsakže, vskralevstvovati, vspuĉenv, vhodoč'stvo, včediti, voplstvovati, vêĉ̉nstvo, gravaonoskb, gramota $^{2}$, dvoino $\hat{u}$, dvornostb, dosbzdati, drêvolı, dunastb, dêtirb. $\left(\sum: 11+16=\right.$ 27)

BrVO: balinoskb, bezlêpie, beskonbčno, blagovolstvie, blagoprêbivanie, bogoobêtons, voiknuti, vzvrbčiti, vzvêstovanie, vznoslivb, vivariti, vinositi, visoč'stvie, vitrognuti; vspoplbzatise, včeladiti, glagolitelbnv, gnilnikb, gozambskb, gotovanie, grebiê, d'gota (!), dobrovolenie, doica, dosaditelno, dosaždatelb, dručiti se, dušegubivb, edinosuĉstvie, edomitb, estostvnê, živlati. $\left(\sum: 14+18=32\right)$

CPar: beĉ́stvo, bubnačnica, večeratelnica, vz'ečevati, vzloviti, vmênevati, voždonb; vskliknutie, vsponositi, vstanutie, vozd'hovati, gbotrb, glumka, etambskb, zagresti $^{2}$, zazviznuti. $\left(\sum: 7+9=16\right)$

\footnotetext{
${ }^{9}$ Usp. Reinhart 1986.

${ }^{10}$ Usp. Havránek 1929:781, Keipert 1977:51.
} 
Johannes Reinhart: Rijetke riječi u Rječniku crkvenoslavenskoga jezika hrvatske redakcije FILOLOGIJA 68(2017), 157-169

PsFr: arodii, bezavistno, bezvêrstvie, beslušlivb, besprêstamne, beĉestbnu, becinôu, bivaemoe, blagovêstno, blagodêtelb ${ }^{2}$, blagostno, blagot'čbno, blažstvovati, bêdnotropnê, vzvêrovanie, vzdanie ${ }^{2}$, vzmrbzstvovati, v'oruževati; vskoreniti se, vspeti, vêrovêrbnb, vêčnê, vêsto, gigantovb, goneziti, dobrodarstviti, dogmatisati, drbžavno, drbzovati, edinozračbnv, zakonoprêstupnê, dobrovêsto. $(\Sigma: 18+14=32)$

Ponekad pri analizi rijetkih riječi važnu ulogu ima i tekstologija. To se odnosi s jedne strane na usporedbu riječi iz Rječnika s hrvatskoglagoljskim spomenicima ili tekstovima koji nisu bili ekscerpirani u tom Rječniku. U nekim slučajevima moglo bi se pokazati da rijetke riječi Rječnika nisu u hrvatskoglagoljskoj književosti unikatne. Pogledajmo sljedeće primjere:

vêrbnstvie (MVat ${ }_{4}$; molitva br. 757)] = Kph

gbotru (CPar)] usp. CPet (Tlkovanie evanjeliê) $)^{11}$

dozrênie $\left(\mathrm{MVat}_{4} ;\right.$ Eccli 39.4)] $=\mathrm{Kph} * 2 \mathrm{Vrb}$

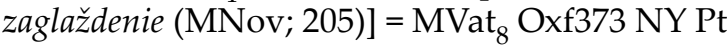

U tri spomenuta primjera iz misala (vêrbnstvie, dozrênie, zaglaždenie) i u primjeru iz Pariškog zbornika (gbotrb) pokazuje se da se pretpostavljena unikatnost leksema gubi ako uzmemo u obzir i druge rukopise.

U sljedećim se primjerima uspoređuje čitanje hrvatskoglagoljskih rukopisa s rukopisima drugih crkvenoslavenskih redakcija:

PsFr: arodii (CommPs 103.17)] arodii (Jagić 1907:495); bezavistno (CommPs 144.15)] bezzzavistrono (Jagić 1907:680-681); bezvêrstvie (CommPs 52.6, 105.15)] bezъvěrijem'; bezbvěrbstvija (Jagić 1907:260, 516); beslušlivb (CommPs 57.6)] beslušliva (Jagić 1907:279); besprêstamne (CommPs 101.10)] beš prěsmene (Jagić 1907:480); beĉestono (CommPs 112.3)] bečostono (Jagić 1907:556); beĉinoû (CommPs 143.13)] be činu (Jagić 1907:676); bivaemoel bivaemaê (CommPs 77.51, 80.8, 77.49)] byvaemoe, byvaemoe, $w$ byvaemycht (Jagić 1907:382, 397, 382); blagovêstno (CommPs 45.12, 64.13)] blagověst tno, blagověst'no (Jagić 1907:227, 306); blagodêtelb² (CommPs 10.1)] blagodětel'mi (Jagić 1907:44); blagostno (CommPs 7.12)] blagost'no (Jagić 1907:29); blagot'čbno (CommPs 146.10)] Blagočestıno (Jagić 1907:688); blažstvovati (CommPs 99.5)] blažbstouetr (Jagić 1907:474); bêdnotropnê (CommPs 147.6)] bědnotroprně (Jagić 1907:690); vzvêrovanie (CommPs 78.9)] vozvěrovanija (Jagić 1907:389); vzdanie (Ps 128.6)] na z'daniich (Jagić 1907:625); vzmrbzstvovati (CommPs 87.9)] Vъzmrbzovašo (Jagić 1907:420); v'oruževati CommPs 36.14)] vrwrǫžąšte (Jagić 1907:174); vskoreniti se (CommPs 51.7)] vkoreni(tb) se (Jagić 1907:256); vspeti (CommPs 9.4)] vrospętie (Jagić 1907:34); vêrovêrbno (CommPs 126.5)] věrnychr (Jagić 1907:623); gigantovъ (CommPs 143.2)] gigantovy (Jagić 1907:672); goneziti (CommPs 25.1)] gonežo (Jagić 1907:113); dobrodarstviti (tit. ad Ps 102)] dobrodarbst'viti (Jagić 1907:485); do-

\footnotetext{
${ }^{11}$ Usp. Štefanić 1960:363 (br. 17).
} 
Johannes Reinhart: Rijetke riječi u Rječniku crkvenoslavenskoga jezika hrvatske redakcije FILOLOGIJA 68(2017), 157-169

gmatisati (CommPs 97.8)] dogmatisavъšse (Jagić 1907:470); drbžavno (CommPs 22.5)] drzžavno (Jagić 1907:102); drbzovati (CommPs 77.63)] drøzovašo (Jagić 1907:385); edinozračıno (CommPs 21.22)] edinozračenъ (Jagić 1907:97); zakonoprêstupnê (CommPs 50.7)] zakonoprěstoprono (Jagić 1907:250); dobrovêsto (CommPs 137.7)] dobrě věsto (Jagić 1907:652).

BrVO: vspoplbzati se (Pr 14.19)] Grig vrsspoplbznọtı sę; gnilnikb (R 9.21)] Mat

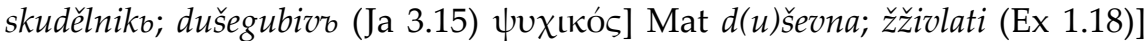
Grig življaete.

CPar: vsponositi (Ps 73.10)] PsLob ponositb; vstanutie (Ps 138.2)] PsLob vstanie; glasovznošenie (Ps 26.6; Ps 32.3; vociferatio)] PsLob vskliknovenie; vsklicanie; glumka (Ps 118.85; fabulatio)] PsLob glumlenie; etamıskb (Ps 73.15)] PsLob etam'; zagresti ${ }^{2}$ (Ps 9.16; infixae sunt)] PsLob uglbbu.

Vidimo da je samosvojnost Fraščićeva pasaltira na leksičkoj razini prouzročena time što leksičko blago komentara u komentiranim psaltirima nije popisivano, barem ne $u$ rječnicima. Promjene dvaju drugih navedenih spomenika, Brevijara Vida Omišljanina i Pariškog zbornika br. 73, nisu tako dalekosežne, ali su uočljivije u Pariškom zborniku nego u Brevijaru Vida Omišljanina.

U nekim slučajevima posrijedi su trenutačne tvorevine, kako su utvrdili obrađivači Rječnika. One nisu uvijek uspješne, i proizlaze iz pogrešne svjesne ili nenamjerne - interpretacije latinskoga izvornika: vskrêsitelno 'suscitando': »translatio minus apta «; dvornostb 'curiositas': "per commutationem curiositas cum curia«.

U jednom slučaju obrađivači su Rječnika zaboravili primijetiti da je riječ d'gna 'rana; cicatrix' iz Fraščićeva psaltira dobro zastupljena u drugim crkvenoslavenskim spomenicima, što dokumentira Miklošičev Rječnik (Miklošič 1862-1865:183, s.v. dъgna): d'gna (PsFr, CommPs 50.3)] dъgno (Jagić 1907:248).

U malobrojnim slučajevima fonetske inačice leksema stekle su status natuknica, prema mojem mišljenju neopravdano: drbzu $\left(\mathrm{BrN}_{2} ;{ }^{*} d r b z o\right)$, d'gota (BrVO; *dlogota).

Ima i riječi koje bi mogle biti povezane s drugim riječima, ili hrvatskoglagoljskim, ili hrvatskim ili (staro-)slavenskim. To se može prikazati na primjeru triju rijetkih riječi iz Rječnika. Glasovni oblik zagonetnoga pri-

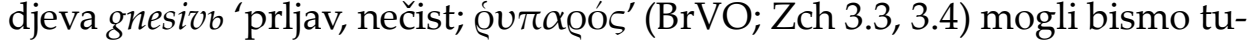
mačiti kao posljedicu srednjobugarske zamjene nazala, pri čemu bi polazišni pridjev bio gnosivo (u hrvatskim spomenicima nije potvrđen) u staroslavenskom izvorniku. Dručiti se 'napredovati' je semantički dosta daleko od staroslavenskoga glagola *drocčiti sę 'mučiti se, patiti' (u kanonskim 
spomenicima - konkretno u Suprasalskom rukopisu - postoje samo riječi dročenije, udročenije i udročiti), ali možda je posrijedi semantička promjena u danom kontekstu. S glagolom dučiti 'grditi, vrijeđati, psovati' mogao bi biti u vezi glagol potvrđen kod Hanibala Lucića - iako njegovo značenje u Akademijinu rječniku ${ }^{12}$ nije točno određeno. Glagol dučiti se, koji dolazi kod nekoliko srpskih pisaca od 18. stoljeća ima prema Akademijinu rječniku značenje 'truditi se, mučiti se' ${ }^{13}$. Značenje 'truditi, mučiti' bolje bi odgovaralo značenju glagoljaškoga glagola, ali za konačno rješenje potrebna su detaljnija istraživanja.

Kao što je bilo već spomenuto, među rijetkim riječima ima nekoliko posuđenica. Germanizam sam našao samo jedan (gbotrb 'kum'; ali usp. također $\left.b o t^{\prime} r b\right)$. I grecizmi - ako zanemarimo indirektne grecizme - dosta su malobrojni (didaskalb, dogmatisati). Najviše je - i to naravno nije iznenađenje - latinizama (dikanb, diêlozi, dunastb, dupleksb, ekšorcista, eneralb, glbtuniê, glbtunb, grapiûnb, graviê).

\section{Zaključak}

Istraživanje rijetkih riječi, takvih koje nisu potvrđene $u$ tri druga rječnika, tvori samo djelomičan aspekt cjelokupnog istraživanja leksika hrvatskoglagoljskoga jezika. Daljnja istraživanja bi morala uzeti u obzir crkvenoslavizme koji nisu potvrđeni u (staro-)hrvatskom jeziku. Nije bez interesa i to koje su riječi potvrđene samo u prijevodima nastalim na području Hrvatske. Kod (staro-)crkvenoslavizama bi bilo zanimljivo ustanoviti u kojim crkvenoslavenskim spomenicima dolaze. Istina, nekoliko je takvih pitanja već obrađeno, npr. u članku o preslavizmima za zadnji slavistički kongres $\mathrm{u}$ Minsku ${ }^{14}$ ili u poglavlju o leksiku u nedavno izdanoj gramatici Hrvatski crkvenoslavenski jezik. ${ }^{15}$

Pregled leksika hrvatsko-crkvenoslavenskoga jezika ograničen je time što dosada izdani svesci Rječnika odražavaju samo dio leksičkog blaga. Ali usprkos tome dobijamo već danas neku sliku leksika toga jezika.

Na kraju htio bih istaknuti da je Rječnik crkvenoslavenskoga jezika hrvatske redakcije odlično polazište i pomoć za različita istraživanja i može biti iskorišten u najrazličitije svrhe.

\footnotetext{
12 Jedini primjer kod Hanibala Lucića glasi: »Ja mńu, ne za drugo hvališ ga i dučišs, nego li za rugo, pokli ga li mučiš.«(RHSJ 2 (Četa - Đavḷi), 1884-1886:851slj.). Glagol ima prema Akademijinu rječniku značenje 'hvaliti'.

13 RHSJ 2 (Četa - Đavḷi), 1884-1886:852.

14 Mihaljević-Šimić 2013.

15 Šimić 2014.
} 
Johannes Reinhart: Rijetke riječi u Rječniku crkvenoslavenskoga jezika hrvatske redakcije FILOLOGIJA 68(2017), 157-169

\section{Literatura}

Bláhová, Emilue. 1997. (Rec.:) Rječnik crkvenoslavenskoga jezika hrvatske redakcije, 1. Uvod, 2.-5. sv., 1991-1995, Slavia 66, 221-223.

Цейтлин, Раля Михайловна. 1977. Аексика старославянского языка. Опыт анализа мотивированных слов по данным древнебодгарских рукописей X-XI вв., Москва: Издательство Наука. 336 str.

Eichner, Heiner, Johannes Reinhart. 1995. (Rez.:) Etymologický slovník jazyka staroslověnského, 3: dělo - gospodb, Praha 1992, S. 129-192; 4: gostı - istonoti, Praha 1994, S. 193-252 + I-IV; 5: istopiti sę - klęti, Praha 1995, S. 253-316.. Wiener Slavistisches Jahrbuch 41, 274-282.

Havránek, Bohuslav. 1929. Příspěvek k tvoření slov ve spisovných jazycích slovanských (Adjektiva s významem latinských adjektiv na -bilis). Slavia 7, 1928/1929, 766-784.

Houtzagers, Hubrecht Peter. 1985. The Čakavian Dialect of Orlec on the Island of Cres. Amsterdam: Rodopi. 415 str. (Studies in Slavic and General Linguistics, vol. 5)

Jagić, Vatroslav. 1907. slověnbskaja psalıtyru - Psalterium Bononiense. Interpretationem veterem slavicam cum aliis codicibus collatam, adnotationibus ornatam, appendicibus auctam. Adiutus Academiae Scientiarum Vindobonensis. liberalitate edidit V. Jagić, Vindobonae - Berolini - Petropoli MDCCCCVII:Gerold \& Soc. - Weidmann - C. Ricker. 968 str.

Keipert, Helmut. 1977. Die Adjektive auf-telınъ. Studien zu einem kirchenslavischen Wortbildungstyp, I. Teil. Wiesbaden: Otto Harrassowitz. 237 str.

Lencek, Rado. 1993. On the Trail of * $v y$-Compounds in South Slavic. U knj. Maguire i dr. (eds.) 1993, 344-362.

Maguire, Robert Alan, Alan Timberlake (eds.). 1993. american contributions to the eleventh international congress of slavists, Bratislava, August - September 1993, Literature, Linguistics, Poetics. Columbus Ohio: Slavica. 459 str.

Mihaljević, Milan (ur.). 2014. Hrvatski crkvenoslavenski jezik. Zagreb: Hrvatska sveučilišna naklada i Staroslavenski institut). 420 str.

Mihaljević, Milan, Marinka Šimić. 2013. Preslavizmi u hrvatskoglagoljskim tekstovima. U knj. Turk 2013, 11-23.

Miklosich, Franc. 1862-1865. Lexicon palaeoslovenico-graeco-latinum. Wien: Guilelmus Braumueller. 1171 str.

RCJHR I = Rječnik crkvenoslavenskoga jezika hrvatske redakcije, I. svezak ( $\mathrm{a}^{1}-$ vrêdb). Zagreb 2000:Staroslavenski institut. 576 str.

RCJHR II = Rječnik crkvenoslavenskoga jezika hrvatske redakcije, II. svezak (vrêdınь - zapovêdnica), Zagreb 2015:Staroslavenski institut. 640 str.

Reinhart, Johannes. 1986. Über den Ursprung des adjektivischen Wortbil-

166 
Johannes Reinhart: Rijetke riječi u Rječniku crkvenoslavenskoga jezika hrvatske redakcije FILOLOGIJA 68(2017), 157-169

dungstyps -telbno im Kroatisch-Kirchenslavischen, Wiener Slavistisches Jahrbuch 32, 65-70.

RHSJ 1-23 = Rječnik hrvatskoga ili srpskoga jezika, Dio 1-23, Zagreb 1880/1882-1975:Jugoslavenska Akademija Znanosti i Umjetnosti.

SDJa II - Словарь древнерусского языка (XI - XIV вв.), Том II (vъzalkati dobrodětelьnikъ), Москва 1989:Русский язык. 494 str.

SJS - Slovník jazyka staroslověnského, I-IV, Praha 1958-1997:Academia; Euroslavica. 3204 str.

SJS V - Slovník jazyka staroslověnského, V, Addenda et corrigenda, sešit 53, Zoe Hauptová (ur.). Praha 2010:Euroslavica. 72 str.

Ružić Sudčev, Šime. 1999. Pićan i pićònski idiomi. Pula: C. A. S. H. 159 str.

Šimić, Marinka. 2014. Leksik. U knj. Mihaljević (ur.) 2014, 365-392.

Štefanić, Vjekoslav. 1960. Glagoljski rukopisi otoka Krka. Zagreb: Jugoslavenska Akademija znanosti i umjetnosti. 455 str.

Turk, Marija (ur.). 2013. A tko to ide? A xmo max idze?, Hrvatski prilozi XV. Međunarodnom slavističkom kongresu. Zagreb: Hrvatska sveučilišna naklada i Hrvatsko filološko društvo, 313 str. 


\section{Skraćenice citiranih spomenika}

BrLab - Ljubljanski brevijar (kraj 14. st.)

$\mathrm{BrN}_{2}$ - II. novljanski braevijar (1495.)

BrPm - Pašmanski brewvijar (druga pol. 14. i 15. st.)

BrVO - Brevijar Vida Omišljanina (1396.)

CAc - Zbornik duhovnog štiva (kraj 15. st.)

CBč - Zbornik u Berčićevoj zbirci br. 5 (15. st.)

COxf - Oxfordski zbornik (15. st.)

CPar - Pariški zbornik (1375.)

CPet - Petrisov zbornik (1468.)

CŽg - Žgombićev zbornik (16. st.)

Grig - Grigorovičev parimejnik (12. st.)

Kph - Kopenhagenski misal (kraj 14. st.)

Mar - Marijinsko četveroevanđelje (10. - 11. st.)

Mat - Matičin apostol (13. st.)

MNov - Misal kneza Novaka (1368.)

MVat $_{4}$ - Misal Illirico 4 (druga polovica 14. st.)

MVat $_{8}$ - Misal Illirico 8 (1435.)

NY - Newyorški misal (15. st.)

Oxf373: Oxfordski misal 373 (1463.)

PsFr - Fraščićev psaltir (1463.)

PsLob - Lobkovicov psaltir (1359.)

Pt - Prvotisak misala (1483.)

2Vrb - II. vrbnički misal (1462.) 
Johannes Reinhart: Rijetke riječi u Rječniku crkvenoslavenskoga jezika hrvatske redakcije

FILOLOGIJA 68(2017), 157-169

\title{
Rare words in the Rječnik crkvenoslavenskoga jezika hroatske redakcije
}

\begin{abstract}
In this paper words in the first two volumes of the Dictionary of the Croatian redaction of the Church Slavonic language (Rječnik crkvenoslavenskoga jezika hrvatske redakcije, 2000 and 2015) are analyzed that are not attested either in the Prague Old Church Slavonic dictionary nor in Miklošičs's Church Slavonic dictionary nor in the Academic dictionary of the South Slavic Academy. They are called rare words in this paper. The two volumes of the Dictionary contain about 2050 head-words each, among them we counted 306 and 262 rare words, respectively. Some of these words are not particularly significant from the point of view of historical lexicology, e.g. proper names from the Bible or derivational variants of frequently attested words. In the analysis special attention is paid to word formation and textology. Rare words from the Dictionary not known from other dictionaries nor from the contemporary Croat language do often contribute to a better understanding of the history of the language.

Ključne riječi: crkvenoslavenski jezik hrvatske redakcije, Rječnik crkvenoslavenskoga jezika hrvatske redakcije, povijesna leksikologija hrvatskoga jezika, tvorbene inačice

Keywords: Croatian redaction of Church Slavonic, the Dictionary of Church Slavonic of the Croatian redaction (Rječnik crkvenoslavenskoga jezika hrvatske redakcije), historical lexicology of Croat, derivational variants
\end{abstract}


